\title{
DEVELOPMENT OF ASYNCHRONOUS BLENDED LEARNING (ABLE) SKILLS LAB WITH PEER EVALUATION IN MIDWIFERY STUDENTS
}

\author{
Dita Eka Mardiani ${ }^{1 *}$, Dedi Rachmadi², Deni K Sunjaya², Ike R Husen² \\ ${ }^{1}$ Program Studi Magister Kebidanan Universitas Padjadjaran, Bandung - INDONESIA \\ ${ }^{2}$ Fakultas Kedokteran, Universitas Padjadjaran, Bandung - INDONESIA
}

Submitted: 15 August 2019; Final Revision from Author: 10 October 2020; Accepted: 15 October 2020

\begin{abstract}
Background: Innovations in midwifery education is needed to strengthen students' skills. The Asynchronous Blended Learning (ABLE) Skills Lab model can improve student motivation, retention and skills, but the evaluation is still not optimal. One solution to overcome it by developing of the ABLE Skills Lab with Peer Evaluation model. This study aims to analyze the differences in the improvement of newborn resuscitation skills between the application of the ABLE Skills Lab model with Trainer Evaluation and Peer Evaluation.
\end{abstract}

Methods: This study used a quasy experimental two group pre-post test design. The participants involved in this research were 40 students of the fourth semester students of Diploma III Poltekkes Kemenkes Tasikmalaya who met the inclusion criteria. Subjects were divided into 4 learning groups that randomized into 2 research groups. Data were analyzed using inferential statistics and Rasch modelling.

Results: There is no difference in the improvement of newborn resuscitation skills between the application of the ABLE Skills Lab with Trainer Evaluation model and ABLE Skills Lab with Peer Evaluation model $(p=0,344)$.

Conclusion: ABLE Skills Lab with Peer Evaluation model has the same ability with Trainer Evaluation model in improving newborn resuscitation skills.ABLE Skills Lab with Peer Evaluation can be an alternative method when there are limited staff/instructors during the learning process without reducing the output produced.

Keywords: ABLE skills lab, neonatal resuscitation skills, peer evaluation, trainer evaluation

\begin{abstract}
ABSTRAK
Latar belakang: Inovasi dalam pendidikan kebidanan yang sesuai dengan perkembangan zaman perlu dilakukan untuk dapat memperkuat penguasaan keterampilan peserta didik. Model Asynchronous Blended Learning (ABLE) Skills Lab dapat meningkatkan motivasi, retensi dan keterampilan mahasiswa, namun evaluasi yang dilakukan belum optimal. Salah satu upaya yang dapat dilakukan untuk mengatasinya adalah dengan pengembangan ABLE Skills Lab dengan Peer Evaluation. Penelitian ini bertujuan untuk menganalisis perbedaan peningkatan keterampilan resusitasi bayi baru lahir antara model ABLE Skills Lab dengan Trainer Evaluation dan Peer Evaluation.
\end{abstract}

Metode: Penelitian ini merupakan penelitian kuantitatif dengan rancangan quasy experimental two group prepost test design. Responden dalam penelitian ini berjumlah 40 orang, yang terbagi ke dalam 2 kelompok penelitian. Data dianalisis dengan statistik inferensial dan pemodelan Rasch.

*corresponding author, contact: ditaekamardiani90@gmail.com 
Hasil: Tidak terdapat perbedaan peningkatan keterampilan resusitasi bayi baru lahir antara penerapan model ABLE Skills Lab dengan Trainer Evaluation dan model ABLE Skills Lab dengan Peer Evaluation ( $\mathrm{p}=0,344)$.

Kesimpulan: Model ABLE Skills Lab dengan Peer Evaluation memiliki hasil yang sama dengan Trainer Evaluation dalam meningkatkan keterampilan resusitasi bayi baru lahir pada mahasiswa. Evaluasi dengan peer dapat menjadi jalan keluar di saat adanya keterbatasan tenaga/instruktur saat proses pembelajaran tanpa mengurangi output yang dihasilkan.

Kata kunci: ABLE Skills Lab, Keterampilan Resusitasi Bayi Baru Lahir, Peer Evaluation, Trainer Evaluation

\section{PRACTICE POINTS}

- ABLE Skills Lab dapat diaplikasikan pada kegiatan pembelajaran mahasiswa kebidanan pada tahap pra klinik

- ABLE Skills Lab dengan Peer Evaluation dapat meningkatkan keterampilan mahasiswa

- ABLE Skills Lab dengan Peer Evaluation dapat menjadi jalan keluar di saat adanya keterbatasan tenaga/instruktur saat proses pembelajaran tanpa mengurangi output yang dihasilkan.

\section{PENDAHULUAN}

Kualitas pendidikan saat ini masih menjadi permasalahan mendasar dalam usaha perbaikan mutu pendidikan nasional. Banyaknya jumlah institusi pendidikan kebidanan pada nyatanya belum mampu menjawab tantangan kebutuhan bidan yang kompeten. ${ }^{1,2}$ Hasil uji kompetensi bidan periode XI tahun 2018 menunjukkan sebagian besar peserta tidak lulus uji kompetensi $(79,7 \%){ }^{3}$ Di samping itu, hasil evaluasi penyelenggaraan pendidikan DIII Kebidanan di 5 provinsi menunjukkan bahwa sebagian besar mahasiswa memiliki keterampilan yang kurang. ${ }^{1}$

Berdasarkan Kepmenkes RI nomor 369/MENKES/ SK/III/2007 tentang Standar Profesi Bidan, terdapat beberapa keterampilan klinik yang harus dikuasai oleh seorang bidan diantaranya adalah penanganan kegawatdaruratan pada bayi baru lahir yang memiliki kesulitan bernafas/asfiksia. ${ }^{2}$ Resusitasi merupakan manajemen pada bayi baru lahir dengan asfiksia. ${ }^{4}$ Manajemen asfiksia pada bayi baru lahir menjadi suatu perhatian dalam upaya penurunan Angka Kematian Bayi (AKB) di Indonesia yang masih tinggi, dimana asfiksia menjadi penyebab kematian terbesar kedua pada bayi baru lahir. Oleh karena itu, keterampilan dalam pelaksanaan resusitasi neonatus wajib dikuasai oleh seorang bidan untuk menjamin keamanan dan kesehatan bayi baru lahir dalam rangka memberikan pelayanan kebidanan yang berkualitas. ${ }^{5}$

Pendidikan bidan yang berkualitas diperlukan untuk membentuk lulusan yang berkualitas. Untuk menghasilkan lulusan yang berkualitas dipengaruhi berbagai faktor, diantaranya adalah proses pembelajaran. Di dalam suatu proses pembelajaran kebidanan perlu dilakukan inovasi, seperti metode pembelajaran yang dapat menstimulasi critical thinking, analisis dan self learning serta memperkuat penguasaan keterampilan peserta didiknya sehingga dapat menghasilkan bidan yang kompeten. Revolusi Industri 4.0 menuntut adanya inovasi dan transformasi dalam proses pembelajaran. Salah satu inovasi metode pembelajaran yang mengakomodir kebutuhan saat ini adalah blended learning.

Penelitian mengenai penerapan Asynchronous Blended Learning (ABLE) Skills Lab menunjukkan adanya peningkatan terhadap motivasi dan keterampilan klinis mahasiswa. Namun pada penelitian tersebut menimbulkan kesulitan bagi dosen dalam melakukan penilaian dan pemberian feedback di luar jam kerja yang menyita waktu. ${ }^{6}$ Pemilihan penerapan evaluasi (assessment) dalam pembelajaran sebagai salah satu 
solusi alternatif dikarenakan kemampuan assessment yang dipandang dapat meningkatkan motivasi mahasiswa dalam belajar. Upaya untuk mengatasi kesulitan dosen dalam melakukan penilaian sekaligus bisa memberikan umpan balik (feedback) kepada mahasiswa terhadap tugas yang telah dikerjakannya, maka dosen bisa berkolaborasi dengan mahasiswa menggunakan peer evaluation. ${ }^{7}$ Oleh karena itu, peneliti tertarik untuk melakukan pengembangan ABLE Skills Lab dengan Peer Evaluation. Penelitian ini bertujuan untuk menganalisis perbedaan peningkatan keterampilan resusitasi bayi baru lahir antara penerapan model ABLE Skills Lab dengan Trainer Evaluation dan Peer Evaluation.

\section{METODE}

Penelitian ini menggunakan metode kuantitatif dengan rancangan quasy experimental two group prepost test design. Penelitian dilaksanakan di Poltekkes Kemenkes Tasikmalaya. Subjek penelitian adalah mahasiswa semester IV prodi DIII Kebidanan yang memenuhi kriteria inklusi dengan jumlah 40 orang. Teknik pengambilan sampel adalah total sampling.

Subjek dibagi menjadi 4 kelompok pembelajaran yang dirandomisasi ke dalam 2 kelompok penelitian, yaitu kelompok I (ABLE Skills Lab denganTrainer Evaluation) dan kelompok II (ABLE Skills Lab dengan Peer Evaluation). Tiap kelompok pembelajaran didampingi oleh 1 trainer.

Pada saat online learning, responden diberikan materi mengenai keterampilan resusitasi bayi baru lahir, selanjutnya diberikan penugasan untuk melakukan simulasi keterampilan dengan cara direkam. Video hasil rekaman diupload ke platform google classroom untuk selanjutnya dilakukan evaluasi. Pada kelompok I, trainer mengevaluasi dan memberikan feedback, sementara pada kelompok II mahasiswa mengevaluasi dan memberikan feedback antar teman. Feedback yang diberikan diupload ke dalam kelas di google classroom untuk dapat dilihat oleh tiap-tiap mahasiswa sehingga diharapkan mahasiswa dapat berlatih kembali berdasarkan hasil review.
Pada saat pertemuan tatap muka, trainer melakukan fasilitasi diskusi dan demonstrasi keterampilan. Selanjutnya, pada kelompok I mahasiswa melakukan simulasi perbaikan dari hasil review trainer, sementara pada kelompok II, secara acak mahasiswa mempresentasikan hasil review terhadap temannya, dan mahasiswa yang dilakukan review melakukan simulasi perbaikan berdasarkan review.

Tiap responden diukur keterampilan resusitasi bayi baru lahir saat pretest dan postest oleh 2 trainer dengan menggunakan daftar tilik standar di Poltekkes Kemenkes Tasikmalaya. Uji validitas instrumen dilakukan dengan pemodelan Rasch menggunakan uji dimensionality dengan nilai raw variance explained by measure $=43,3 \%$ yang berarti memiliki kriteria baik. Semantara itu, hasil uji reliabilitas instrumen menghasilkan nilai person reliability dengan nilai 0,77 yang bermakna kualitas respon subjek dalam menjawab setiap pertanyaan adalah cukup; nilai Chronbach Alpha sebesar 0,8 serta nilai item reliability sebesar 0,93 yang bermakna kualitas instrumen yang digunakan bagus sekali.

Data yang terkumpul dari hasil penilaian diolah dan dianalisis dengan menggunakan pemodelan Rasch untuk menghasilkan skala logit, kemudian dilakukan analisis statistik inferensial. Penelitian ini telah mendapatkan izin dari Komisi Etik Penelitian Kesehatan Fakultas Kedokteran Universitas Padjadjaran dengan nomor: 292/UN6.KEP/ EC/2019.

\section{HASIL DAN PEMBAHASAN}

Tabel 1 di bawah ini menunjukkan hasil uji statistik gambaran karakteristik subjek penelitian menunjukkan kelompok ABLE Skills Lab dengan Trainer Evaluation memiliki mean IPK yang lebih tinggi. Jumlah mahasiswa yang memiliki predikat IPK “Dengan Pujian” lebih banyak pada kelompok ABLE Skills Lab dengan Trainer Evaluation meskipun secara statistik tidak adanya perbedaan yang bermakna ( $p>0,05)$, sehingga kedua kelompok layak diperbandingkan. 
Tabel 1. Karakteristik Subjek Penelitian

\begin{tabular}{|c|c|c|c|}
\hline \multirow[b]{2}{*}{ Karakteristik } & \multicolumn{2}{|c|}{ Metode Pembelajaran } & \multirow{2}{*}{$\begin{array}{c}\text { Nilai } \\
\mathrm{p}\end{array}$} \\
\hline & $\begin{array}{l}\text { ABLE Skills Lab Trainer Evaluation } \\
\text { (Kelompok I) }\end{array}$ & $\begin{array}{l}\text { ABLE Skills Lab Peer Evaluation } \\
\text { (Kelompok II) }\end{array}$ & \\
\hline $\begin{array}{l}\text { IPK } \\
\qquad \text { Mean (SD) } \\
\text { Median } \\
\text { Rentang }\end{array}$ & $\begin{array}{c}3,39(0,2) \\
3,39 \\
3,06 \text { s.d } 3,78\end{array}$ & $\begin{array}{c}3,31(0,16) \\
3,31 \\
3,06 \text { s.d } 3,63\end{array}$ & 0,140 \\
\hline $\begin{array}{l}\text { Sangat Memuaskan } \\
(2,76-3,50) \\
\text { Dengan Pujian } \\
(3,51-4,00)\end{array}$ & 14 & 18 & \\
\hline
\end{tabular}

Keterangan: $\mathrm{t}=1,501$

Tabel 2 menyajikan hasil yang didapatkan bahwa keterampilan mahasiswa dalam melakukan tindakan resusitasi bayi baru lahir sebelum penerapan metode pembelajaran menunjukkan ada perbedaan yang bermakna baik dari hasil penilaian rater I $(p=0,001)$ maupun rater II $(\mathrm{p}=0,014)$, begitupun pada pengamatan setelah penerapan metode pembelajaran menunjukkan adanya perbedaan yang bermakna pada kedua kelompok dari hasil penilaian rater I $(\mathrm{p}<0,001)$ dan penilaian II $(\mathrm{p}=0,008)$.

Tabel 2. Perbedaan Keterampilan Resusitasi Bayi Baru Lahir Antara Kedua Kelompok

\begin{tabular}{|c|c|c|c|}
\hline \multirow[b]{2}{*}{ Logit Keterampilan } & \multicolumn{2}{|c|}{ Metode Pembelajaran } & \multirow{2}{*}{$\begin{array}{c}\text { Nilai } \\
p^{*}\end{array}$} \\
\hline & $\begin{array}{l}\text { ABLE Skills Lab Trainer Evaluation } \\
\text { (Kelompok I) }\end{array}$ & $\begin{array}{l}\text { ABLE Skills Lab Peer Evaluation } \\
\text { (Kelompok II) }\end{array}$ & \\
\hline \multicolumn{4}{|l|}{ Rater I } \\
\hline $\begin{array}{l}\text { Pre Test } \\
\quad \text { Mean (SD) } \\
\text { Rentang }\end{array}$ & $\begin{array}{l}-2,28(1,07) \\
-4,39 \text { s.d }-0,36\end{array}$ & $\begin{array}{l}-1,52(0,96) \\
-4,39 \text { s.d } 0,21\end{array}$ & $0,001^{*}$ \\
\hline $\begin{array}{l}\text { Postest } \\
\text { Mean (SD) } \\
\text { Rentang }\end{array}$ & $\begin{array}{l}2,18(0,76) \\
0,7-3,34\end{array}$ & $\begin{array}{l}3,77(1,15) \\
1,81-6,92\end{array}$ & $<0,001^{*}$ \\
\hline $\begin{array}{l}\text { Kenaikan } \\
\text { Mean (SD) } \\
\text { Rentang }\end{array}$ & $\begin{array}{l}4,31(1,23) \\
2,30-7,19\end{array}$ & $\begin{array}{l}5,8(1,56) \\
3,06-8,74\end{array}$ & $0,096^{* *}$ \\
\hline Perbandingan Pre dan Post Test & $<0,001^{* * *}$ & $<0,001^{* * *}$ & \\
\hline \multicolumn{4}{|l|}{ Rater II } \\
\hline $\begin{array}{l}\text { Pre Test } \\
\quad \text { Mean (SD) } \\
\text { Rentang }\end{array}$ & $\begin{array}{l}-2,44(1,09) \\
-4,39 \text { s.d }-0,8\end{array}$ & $\begin{array}{l}-1,63(0,91) \\
-4,39-0,8\end{array}$ & $0,014^{* *}$ \\
\hline $\begin{array}{l}\text { Postest } \\
\text { Mean (SD) } \\
\text { Rentang }\end{array}$ & $\begin{array}{l}3,77(1,15) \\
1,81-6,92\end{array}$ & $\begin{array}{l}3,77(1,11) \\
1,24-6,92\end{array}$ & $0,008^{*}$ \\
\hline $\begin{array}{l}\text { Kenaikan } \\
\text { Mean (SD) Rentang }\end{array}$ & $\begin{array}{l}5,24(1,52) \\
2,97-8,74\end{array}$ & $\begin{array}{l}5,4(1,59) \\
2,98-9,21\end{array}$ & $0,749^{*}$ \\
\hline Perbandingan Pre dan Post Test & $<0,001^{* * * *}$ & $<0,001^{* * * *}$ & \\
\hline
\end{tabular}

* Uji T Tidak berpasangan *** Uji T Berpasangan

** Uji Mann Whitney **** Uji Wilcoxon 
Pembelajaran praktek laboratorium klinik (skills lab) merupakan tahapan pembelajaran yang penting dari proses pendidikan kebidanan yang bertujuan mengimplementasikan pembelajaran teori di kelas dan mempersiapkan peserta didik dalam melaksanakan praktek di lahan praktek atau situasi nyata. Beberapa komponen penting yang menentukan keberhasilan suatu pembelajaran klinik, diantaranya adalah metode atau strategi pelatihan.

Pada penelitian ini dirancang suatu strategi pelatihan blended learning secara asynchronous (tidak langsung) pada kedua kelompok dengan proses evaluasi yang berbeda. Blended learning merupakan perpaduan dari pengalaman belajar secara tatap muka (face to face) dan pembelajaran secara daring yang digabungkan menjadi sebuah pengalaman belajar yang unik, pada prinsipnya mengsintesis kelebihan dari kedua metode pembelajaran baik tradisional maupun e-learning. ${ }^{8,9}$

Sebuah penelitian meta analisis oleh Liu $\mathrm{dkk}^{9}$ pada pendidikan kedokteran menunjukkan bahwa blended learning memiliki efek positif yang konsisten dibandingkan dengan konvensional dan sama efektifnya dengan non-blended untuk akuisisi pengetahuan pada tenaga medis. Dalam ABLE Skills $L a b$, proses belajar melalui pelatihan keterampilan secara blended learning dapat mendorong mahasiswa untuk belajar mandiri (self learning) sehingga dapat mengaktifkan metacognitive thinking dan menjadikan proses pembelajaran kontruktif. ${ }^{10}$

Di samping adanya kemampuan metakognisi, belajar berbasis pengalaman (experiential learning) dalam hal ini penugasan yang diberikan mampu merangsang aktivitas mahasiswa untuk dapat terus berlatih secara berulang (reherseal) sampai mahir sehingga mahasiswa dapat mengupload rekaman hasil simulasi ke platform google classroom. Pada hal inilah pengetahuan dikonstruksi melalui transformasi pengalaman. Experiential learning merupakan proses pembelajaran yang mengaktifkan pembelajar untuk membangun pengetahuan dan keterampilan melalui pengalamannya secara langsung. ${ }^{11}$

Adapun evaluasi (penilaian) di dalam aktivitas pembelajaran dapat dilaksanakan dengan tiga pendekatan yaitu assesment of learning, assessment for learning dan assessment as learning. ${ }^{12}$ Pada penelitian ini, kegiatan evaluasi dilakukan sebagai assessment for learning yang merupakan kegiatan penilaian yang dilakukan selama proses pembelajaran berlangsung dan digunakan sebagai dasar untuk perbaikan proses belajar.

Proses evaluasi tidak terlepas dengan pemberian feedback (umpan balik). Feedback diperlukan dalam proses pembelajaran untuk mencapai tujuan pembelajaran secara maksimal. Feedback tersebut berguna bagi mahasiswa untuk mengevaluasi diri, mengetahui kesalahan-kesalahan yang terjadi dalam proses penyelesaian masalah, mengetahui kelemahan diri, serta membantu mahasiswa untuk meningkatkan motivasi dan rasa percaya diri dalam belajar sehingga dapat meningkatkan kemampuan dalam penguasaan konsep materi yang telah diberikan. Bila bentuk umpan balik ini tepat maka hasil yang dicapai oleh mahasiswa akan menjadi penguatan (reinforcement) untuk terulangnya kembali perilaku yang positif. ${ }^{13,14}$

Pada penelitian ini menggunakan 2 metode evaluasi yakni evaluasi yang dilakukan oleh trainer (trainer evaluation) dan evaluasi yang dilakukan antar teman sebaya (peer evaluation) dimana masing-masing metode memiliki keunggulan dan kelemahan.

Hasil penelitian menunjukkan perbedaan yang bermakna pada perbandingan nilai pretest-postest pada kelompok I baik dari rater I maupun rater II $(\mathrm{p}<0,05)$. Hal ini dapat dikatakan bahwa penerapan model ABLE Skills Lab dengan Trainer Evaluation berpengaruh terhadap peningkatan keterampilan mahasiswa. Evaluasi oleh trainer memiliki kelebihan yakni kualitas feedback yang diberikan, namun pada beberapa dosen kesulitan memberikan feedback karena memerlukan waktu yang lebih banyak terlebih jika kelas dalam jumlah besar. ${ }^{15}$

Pada saat sesi pembelajaran tatap muka, peran trainer untuk meluruskan miskonsepsi pada mahasiswa saat fase self learning, dimana trainer mendemonstrasikan praktik resusitasi bayi baru lahir, mahasiswa akan merefleksikan kembali pengalaman praktik sebelumnya yang telah mereka kerjakan.

Pada kelompok ABLE Skills Lab dengan Trainer Evaluation, proses penilaian dan pemberian umpan 
balik (feedback) yang dilakukan trainer antara lain memberikan penjelasan terhadap kesalahan yang dilakukan mahasiswa dalam menyelesaikan tugas yang diberikan serta memberikan arahan untuk perbaikan langkah keterampilan.

Dosen/trainer merupakan evaluator peserta didik yang paling umum. Penelitian mengenai evaluasi formatif yang dilakukan oleh dosen menunjukkan efek positif pada pembelajaran dan sikap peserta didik. ${ }^{15}$ Pada penelitian ini, trainer mengevaluasi dengan melihat video mahasiswa yang telah di-upload, lalu diberikan feedback melalui platform google classroom untuk kemudian dipelajari mahasiswa.

Feedback trainer merupakan bagian dari pengaturan pembelajaran eksternal (external regulation). Arahan yang diberikan oleh trainer mengenai apa yang telah dikerjakan dibandingkan dengan tujuan pembelajaran sehingga mahasiswa menganggapnya sebagai suatu informasi dan menggunakannya untuk regulasi internal dari pembelajaran. Regulasi internal berkontribusi pada pembelajaran dalam dua cara yakni secara kognitif, ketika mahasiswa mengambil langkah-langkah selanjutnya untuk perbaikan, dan secara motivasi, ketika mahasiswa berkembang untuk memahami pengendaliannya atas pembelajaran. ${ }^{16}$

Hasil yang sama ditunjukkan pada kelompok II baik hasil penilaian rater I maupun rater II $(\mathrm{p}<0,001)$, sehingga dapat disimpulkan bahwa model ABLESkills Lab dengan Peer Evaluation terbukti berpengaruh dalam meningkatkan keterampilan resusitasi bayi baru lahir pada mahasiswa.

Penelitian sejenis mengenai online peer assesment secara signifikan berpengaruh terhadap kualitas pencapaian learning outcomes mahasiswa. ${ }^{17} \mathrm{Hal}$ ini dapat terjadi karena adanya kesempatan mahasiswa untuk mengevaluasi hasil pekerjaan (tugas) temannya dan memberikan feedback. Proses evaluasi disini sebagai bagian dari proses belajar mahasiswa (assesment as learning). Pada peer evaluation, mahasiswa mendapatkan manfaat yang lebih ketika bertindak sebagai assessor (penilai) daripada assessee (yang dinilai), khususnya berkaitan dengan aktivitas dalam mengidentifikasi kekurangan temannya ketika sedang menilai dan memberikan saran. Hal ini cukup beralasan karena proses tersebut dapat mengarahkan mahasiswa untuk terlibat dalam kegiatan yang menuntut proses kognitif yang lebih tinggi.

Berbeda halnya dengan assessee, feedback dapat mempengaruhi secara tidak langsung melalui pemahaman. Ketika menerima feedback, pertamatama mereka harus memahami secara keseluruhan kekurangan yang ditunjukkan atau saran yang diberikan. Pemberian feedback lebih efektif jika bersifat spesifik (khusus) dibanding feedback secara umum, selain itu lebih baik diberikan segera (immediate feedback).

Dalam peer evaluation, penilaian dan kualitas feedback yang diberikan pada proses evaluasi tergantung dari kemampuan assessor. ${ }^{18}$ Dalam hal ini dapat memungkinkan mahasiswa yang memiliki prestasi akademik yang lemah memiliki kemampuan menilai yang kurang atau kualitas feedback yang diberikan kurang. Oleh karena itu, agar pelaksanaan peer evaluation berjalan maksimal, perlu diberikan penjelasan-penjelasan mengenai indikator/kriteria penilaian. Namun jika dikaitkan dengan proses belajar, manfaat dari proses tersebut adalah dapat lebih melibatkan proses metacognitive thinking. Dalam konteks pendidikan kesehatan, adanya kemampuan metakognisi mendorong peserta didik lebih baik dalam menggunakan pengetahuan medis dasar untuk memberikan penilaian klinis, berpikir kritis (critical thinking), dan melakukan refleksi pada kegiatan praktiknya. ${ }^{19}$

Tabel 2 menyajikan hasil dimana kenaikan skala logit keterampilan mahasiswa pada saat pretest dan postest menunjukkan tidak terdapat perbedaan yang bermakna antara kelompok ABLE Skills Lab dengan trainer evaluation dan peer evaluation $(p>0,05)$. Dalam hal ini dapat dikatakan evaluasi dengan cara peer memiliki hasil yang sama dengan Trainer Evaluation dalam meningkatkan keterampilan resusitasi bayi baru lahir.

Hasil penelitian ini sejalan dengan penelitian Ozugul $^{15}$ bahwa peer evaluation dapat meningkatkan efektifitas dan kualitas pembelajaran sama baiknya dengan teacher evaluation. Berbeda halnya dengan penelitian Mehrdad ${ }^{20}$ yang membandingkan self, peer dan trainer evaluation pada mahasiswa keperawatan 
saat evaluasi praktik klinik di lahan praktek, dimana hasilnya terdapat perbedaan yang signifikan antara skor rata-rata peer dan trainer evaluation, serta self dan trainer evaluation. Mahasiswa dengan peer evaluation memiliki skor rata-rata yang lebih tinggi dibanding self dan teacher evaluation.

Tabel 3. Perbedaan Kenaikan Rata-rata Keterampilan Resusitasi Bayi Baru Lahir dari Kedua Kelompok

\begin{tabular}{lcc}
\multicolumn{1}{c}{ Metode } & \multicolumn{2}{c}{ Keterampilan } \\
\cline { 2 - 3 } & \multicolumn{1}{c}{$<$ Mean $(5,03)$} & $>(40 \%)$ \\
ABLE Skills Lab Trainer Evaluation & $12(60 \%)$ & $11(55 \%)$ \\
ABLE Skills Lab Peer Evaluation & $9(45 \%)$ & $(5,03)$ \\
RR (IK 95\%) & \multicolumn{2}{c}{$1,33(0,73-2,43)$} \\
\hline
\end{tabular}

Keterangan : *Chi Square Test

RR (IK 95\%) : Resiko Relatif dalam Interval Kepercayaan 95\%

Tabel 3 menyajikan hasil yang didapatkan bahwa mahasiswa pada kelompok ABLE Skills dengan Peer Evaluation mengalami peningkatan keterampilan yang lebih banyak (55\%) dibanding kelompok ABLE Skills dengan Trainer Evaluation. Pada tabel tersebut juga didapatkan bahwa mahasiswa yang mendapatkan metode pembelajaran ABLE Skills Lab dengan Trainer Evaluation memiliki resiko 1,33 kali untuk terjadinya peningkatan keterampilan resusitasi bayi baru lahir yang lebih rendah dibandingkan mahasiswa yang diberikan metode ABLE Skills Lab dengan Peer Evaluation meskipun secara statistik menunjukkan tidak ada perbedaan kenaikan yang bermakna.

Berdasarkan pengamatan peneliti, pemberian feedback pada kelompok ABLE Skills Lab dengan Peer Evaluation terhitung lebih cepat dibandingkan dengan kelompok Trainer Evaluation. Kolaborasi dengan peserta didik dalam penilaian dan pemberian umpan balik terhadap rekannya dapat mengurangi waktu yang dibutuhkan peserta didik untuk menerima umpan balik mereka. Peer evaluation memungkinkan tugas dinilai segera setelah selesai. Waktu penyelesaian yang lebih cepat dari umpan balik juga telah terbukti meningkatkan kemungkinan adopsi oleh penerima umpan balik. Eksperimen terkontrol yang dilakukan pada Massive Open Online Course (MOOC) menemukan bahwa nilai akhir siswa meningkat ketika umpan balik disampaikan dengan segera (immediate feedback), tetapi tidak jika ditunda 24 jam. ${ }^{21}$ Dalam hal ini tentu menjadi keuntungan tersendiri ketika suatu institusi memiliki SDM (dosen) yang terbatas dimana dosen tidak memiliki waktu yang cukup banyak untuk melakukan evaluasi formatif.

Pada penelitian ini menerapkan Peer Grading dan Peer Feedback pada kelompok ABLE Skills Lab dengan Peer Evaluation dimana siswa menilai langkah-langkah keterampilan dan merilis skor yang didapatkan (Peer Grading) serta memberikan umpan balik (Peer Feedback). Jika dikaitkan dengan pembelajaran saat ini, model ABLE Skills Lab dengan Peer Evaluation merupakan ciri pembelajaran orang dewasa (andragogi), sehingga pembelajaran terpusat pada mahasiswa.

Pada proses peer evaluation biasanya diawali dengan task performance. Setelah performa tersebut, assessor memberikan feedback (feedback provision). Feedback kemudian diterima oleh assessee (feedback reception). Pada akhirnya, assessee akan melakukan performa setelah perbaikan sesuai dengan feedback yang diberikan (feedback revision). Pada kelompok ABLE Skills Lab dengan Peer Evaluation, keempat proses tersebut menjadikan interaksi antar mahasiswa yang dapat merangsang proses kognitif, sehingga mengantarkan pada elaborasi lebih dalam (deep learning) tentang materi yang dipelajari. ${ }^{22}$

Peer evaluation menuntut mahasiswa menyediakan waktu lebih banyak dalam berpikir, membedakan, dan mengkomunikasikan hasil penilaiannya. Selain itu, proses assessor dalam mereview, menyimpulkan, mengklarifikasi, memberikan feedback, menetapkan kesalahpahaman, dan mengetahui kekurangan dari 
teman yang dinilai merupakan bentuk dari proses kognisi dan metakognisi.

Metakognisi memegang peran yang sangat penting dalam aktivitas pembelajaran mahasiswa dalam mengikuti perkuliahan. Apabila mahasiswa memiliki keterampilan metakognisi, mereka akan senantiasa merefleksikan strategi belajar yang mereka lakukan dalam mempelajari materi. ${ }^{10}$ Dalam konteks pendidikan kesehatan, adanya kemampuan metakognisi mendorong peserta didik lebih baik dalam menggunakan pengetahuan medis dasar untuk memberikan penilaian klinis, berpikir kritis (critical thinking), dan melakukan refleksi pada kegiatan praktiknya. ${ }^{19}$

Bagi assessee, proses kognisi dan metakognisi terjadi pada pemahaman kriteria dan standar yang akan dinilai. Pada proses ini juga terjadi collaborative learning, yaitu mahasiswa saling bekerja sama mencapai hasil sesuai dengan yang diinginkan oleh dosen. ${ }^{22}$ Selain itu, sesi presentasi dan diskusi atas feedback yang telah mahasiswa berikan kepada temannya memberikan keuntungan tersendiri dimana mahasiswa akan mengkonstruk pengetahuan baru. Hal inilah yang menjadikan ABLE Skills Lab dengan Peer Evaluation menjadi proses pembelajaran yang konstruktif.

Penelitian ini memiliki kekuatan dan kelemahan. Kekuatannya adalah penelitian mengenai blended learning pada skills lab baru pertama kali dilakukan dengan metode evaluasi "peer evaluation". Proses pembelajaran yang konstruktif pada metode ini dapat meningkatkan keterampilan mahasiswa. Oleh karena itu, evaluasi dengan peer dapat menjadi jalan keluar di saat adanya keterbatasan tenaga/instruktur saat proses pembelajaran tanpa mengurangi output yang dihasilkan. Selama proses penelitian, peneliti memiliki kendala dimana akses jangkauan internet pada beberapa mahasiswa kurang baik saat pembelajaran mandiri. Hal tersebut dapat menyebabkan proses pembelajaran secara daring dapat menjadi kurang optimal.

\section{KESIMPULAN}

Model ABLE Skills Lab dengan Peer Evaluation memiliki kemampuan yang sama dengan Trainer
Evaluation dalam meningkatkan keterampilan resusitasi bayi baru lahir pada mahasiswa. ABLE Skills Lab dengan Peer evaluation lebih banyak melibatkan proses kognisi sehingga dapat meningkatkan kemampuan metakognisi mahasiswa. Kemampuan metakognisi ini dapat mendorong mahasiswa lebih baik dalam menggunakan pengetahuannya untuk memberikan penilaian klinis, berpikir kritis (critical thinking), dan melakukan refleksi pada kegiatan praktiknya sehingga dapat meningkatkan keterampilan klinis (clinical skills).

\section{SARAN}

Pada penelitian yang akan datang supaya menggunakan desain penelitian yang lain dan mengukur variabel retensi keterampilan peserta didik serta mempertimbangkan faktor lain keberhasilan dari ABLE Skills Lab yakni Live Event (Pembelajaran Tatap Muka), Self-Paced Learning (Pembelajaran Mandiri), Student-Teacher Collaboration serta Performance Support Materials (Dukungan Bahan Belajar).

\section{DEKLARASI KEPENTINGAN}

Para penulis mendeklarasikan bahwa tidak terdapat konflik kepentingan apapun terkait studi pada naskah ini.

\section{KONTRIBUSI PENULIS}

Dita Eka Mardiani - bertindak sebagai peneliti, pelaksana di lapangan dalam hal mengawasi jalannya penelitian, dan menulis laporan dan artikel penelitian.

Dedi Rachmadi - membaca awal naskah dan memberikan saran, mengusulkan saran tentang revisi naskah dari editor.

Deni K. Sunjaya - menganalisis data dengan pemodelan Rasch, membaca naskah dan memberikan saran.

Ike Husen - mengusulkan metode ABLE Skills Lab dengan Peer Evaluation, membaca naskah dan memberikan saran. 


\section{DAFTAR PUSTAKA}

1. Rosita R, Hendarwan H, Despitasari M. Evaluasi Penyelenggaraan Pendidikan DIII Kebidanan di 5 Provinsi Wilayah Binaan GAVI. Jurnal Penelitian dan Pengembangan Pelayanan Kesehatan. 2017;1(2):120-30.

2. Indonesia MKR. Keputusan Menteri Kesehatan Republik Indonesia Nomor 369/Menkes/SK/ III/2007 tentang Standar Profesi Bidan. Jakarta: Kemenkes RI. 2007.

3. Data Statistik Uji Kompetensi Bidan [database on the Internet]2018. Available from: http:// ukbidan.ristekdikti.go.id/pages/statistik_lulus

4. Perlman JM, Wyllie J, Kattwinkel J, Atkins DL, Chameides L, Goldsmith JP, et al. Part 11: neonatal resuscitation: 2010 international consensus on cardiopulmonary resuscitation and emergency cardiovascular care science with treatment recommendations. Circulation. 2010;122(16_suppl_2):S516-S38.

5. Ashish K, Wrammert J, Nelin V, Clark RB, Ewald U, Peterson S, et al. Evaluation of Helping Babies Breathe Quality Improvement Cycle (HBB-QIC) on retention of neonatal resuscitation skills six months after training in Nepal. BMC pediatrics. 2017;17(1):103.

6. Adhiyatma AA. Pengaruh Asynchronous Blended Learning Skills Lab Terhadap Keterampilan Klinis dan Motivasi Mahasiswa: Universitas Padjadjaran; 2018.

7. Rahmi YL, Ardi A. Perspektif Mahasiswa Terhadap Peer Assessment dan Self Assessment pada Mata Kuliah Metodologi Penelitian Pendidikan. EKSAKTA. 2017;2:88-91.

8. Rhem J. Blended learning: Across the disciplines, across the academy.Stylus Publishing, LLC.;2012.

9. Liu Q, Peng W, Zhang F, Hu R, Li Y, Yan W. The effectiveness of blended learning in health professions: systematic review and meta-analysis. Journal of medical Internet research. 2016;18(1).

10. Barida M. Keterampilan Metakognisi Mahasiswa Program Studi Bimbingan Dan Konseling Terhadap Mata Kuliah Statistik. Jurnal Psikologi Pendidikan dan Konseling: Jurnal Kajian
Psikologi Pendidikan dan Bimbingan Konseling. 2017:46-54.

11. Prasetya I. Telaah Teoretis Model Experiential Learning dalam Pelatihan Kewirausahaan Program Pendidikan Non Formal. Majalah Ilmiah Pembelajaran. 2011;7(2).

12. Sumintono B, Widhiarso W. Aplikasi pemodelan rasch pada assessment pendidikan. Trim Komunikata;2015.

13. Darungan TS, Rahayu GR, Claramita M. Evaluasi Proses Pemberian Feedback di Tutorial Problem-Based Learning di Fakultas Kedokteran. Jurnal Pendidikan Kedokteran Indonesia; The Indonesian Journal of Medical Education. 2016;5(2):88-100.

14. SERUNI S, HIKMAH N. Pemberian Umpan Balik dalam Meningkatkan Hasil Belajar dan Minat Belajar Mahasiswa. Formatif: Jurnal Ilmiah Pendidikan MIPA. 2015;4(3).

15. Ozogul G, Sullivan H. Student performance and attitudes under formative evaluation by teacher, self and peer evaluators. Educational Technology Research and Development. 2009;57(3):393410.

16. Brookhart SM. Teacher feedback in formative classroom assessment. Leading student assessment. Springer; 2011. hlm. 225-39.

17. Lu J, Law N. Online peer assessment: Effects of cognitive and affective feedback. Instructional Science. 2012;40(2):257-75.

18. Sahin MG, Teker GT, Güler N. An Analysis of Peer Assessment through Many Facet Rasch Model. Journal of Education and Practice. 2016;7(32):172-81.

19. Hong WH, Vadivelu J, Daniel EGS, Sim JH. Thinking about thinking: changes in first-year medical students' metacognition and its relation to performance. Medical education online. 2015;20(1):27561.

20. Mehrdad N, Bigdeli S, Ebrahimi H. A comparative study on self, peer and teacher evaluation to evaluate clinical skills of nursing students. Procedia-Social and Behavioral Sciences. 2012;47:1847-52. 
21. Kulkarni CE, Bernstein MS, Klemmer SR, 22. Kollar I, Fischer F. Peer assessment as editors. PeerStudio: rapid peer feedback collaborative learning: a cognitive perspective. emphasizes revision and improves performance. Learning and Instruction. 2010;20:159-74.

Proceedings of the second (2015) ACM conference on learning@ scale; 2015. 